\title{
EKSISTENSI DAN PENERAPAN PANCASILA SEBAGAI DASAR IDEOLOGI DI ORGANISASI FOKAM (FORUM KOMUNIKASI ANTAR MAHASISWA MUSLIM) UNIVERSITAS DUTA BANGSA SURAKARTA
}

\author{
Widi Nugrahaningsih dan Margaretha Evi Yuliana \\ Universitas Duta Bangsa Surakarta \\ Email: widi_nugrahaningsih@udb.ac.id dan margaretha@udb.ac.id
}

\begin{abstract}
In development, Pancasila as the base of ideology means that every Indonesian citizen is bound all provisions of the Pancasila values even the most basic. The purpose of this research is to know the importance of the application of Pancasila in organizational activities in Indonesia, especially in organizations engaged in religious activities. This research uses a qualitative method, that is by conducting interviews with students who are members of a communication forum between Muslim students at the University of the duta bangsa of Surakarta. The results of the research are the application of Pancasila values in every activity in the Fokam organization. In religious activities do not use informants who allegedly followed the flow that the community said was radical. While in social activities, stick to and uphold the values of tolerance. So that the social activities carried out do not look at ethnicity, race or religion but instead put forward the aspect of expediency.
\end{abstract}

Keywords: Pancasila, The Existence of Pancasila, Ideology

\begin{abstract}
Abstrak
Dalam perkembangannya, Pancasila sebagai dasar Ideologi diartikan bahwa setiap warga negara Indonesia terikat oleh segala ketentuan nilai-nilai Pancasila bahkan yang paling mendasar. Tujuan penelitian ini yaitu untuk mengetahui pentingnya penerapan pancasila dalam kegiatan berorganisasi di Indonesia, khsusnya dalam organisasi yang bergerak dalam kegiatan keagamaan. Penelitian ini menggunakan metode kualitatif, yaitu dengan melakukan wawancara terhadap para mahasiswa yang menjadi anggota forum komunikasi antar mahasiswa muslim di universitas duta bangsa surakarta. Hasil penelitian yaitu tetap diterapkannya nilai-nilai Pancasila dalam setiap kegiatan pada organisasi Fokam. Dalam kegiatan keagamaan tidak menggunakan nara sumber yang diduga mengikuti aliran yang dikatakan masyarakat sebagai aliran radikal. Sedangkan dalam kegiatan sosial, tetap berpegang dan menjunjung nilai-nilai toleransi. Sehingga kegiatan sosial yang dilaksanakan tidak memandang suku, ras maupun agama akan tetapi mengedepankan segi kemanfaatan.
\end{abstract}

Kata kunci: Pancasila, Eksistensi Pancasila, Ideologi 


\section{Pendahuluan}

Pada dasarnya, pancasila sebagai dasar falsafah hidup bangsa Indonesia, menempatkan manusia sebagai ciptaan Tuhan yang memiliki naluri, akhlak dan daya pikir. Bahkan manusia memiliki daya untuk mempertahankan kelangsungan hidupnya atau eksistensi di lingkungan hidupnya dari generasi ke generasi selanjutnya (Asmaroini, 2017). Di Indonesia, pancasila dapat digunakan sebagai landasan bagi seseorang untuk menempatkan, dan mempertahankan terhadap lingkungannya.

Pancasila yang memiliki peranan sebagai dasar negara Indonesia, pada hakikatnya merupakan hasil dari nilai-nilai yang telah tumbuh dalam kehidupan masyarakat Indonesia. Bahkan nilai-nilai Pancasila telah ada sebelum masuknya penjajahan di Indonesia. Ideologi yang memiliki peran sebagai motovasi, menjadikan Nilai-nilai Pancasila ini menuntun bangsa Indonesia hingga mencapai kemerdekaan.

Pancasila yang diambil dari nilai-nilai budaya yang telah hidup dalam diri bangsa Indonesia ini, memperlihatkan bahwa Pancasila merupakan ideologi terbuka. Oleh karena tiap nilai dapat ditemukan di kehidupan sehari-hari bangsa indonesia, selain itu pancasila memiliki sifat yang dinamis. Dalam artian mampu mengikuti perkembangan masyarakat dari segala perubahan. Walaupun Indonesia pernah di jajah oleh bangsa lain, namun nilai-nilai pancasila tetap hidup dalam diri bangsa Indonesia dan tidak berubah.

Ada beberapa faktor yang berkaitan dengan ideologi Pancasila yang di kemukakan oleh (Agus, 2016), yaitu;

1. Adanya pembangunan nasional serta dinamika perkembangan masyarakat.

Perkembangan kehidupan masyarakat menjadikan suatu aturan untuk dapat melakukan perubahan atau pembaharuan sesuai dengan yang dibutuhkan.

2. Adanya kemunduran idiologiter misalnya marxisme komunisme

3. Pengalaman berupa sejarah politik yang terdapat pengaruh komunis

4. Peran Pancasila sebagai asas dalam kehidupan bangsa dan negara Indonesia

Dalam perkembangannya, Pancasila sebagai dasar Ideologi diartikan bahwa setiap warga negara Indonesia terikat oleh segala ketentuan nilai-nilai Pancasila bahkan yang paling mendasar (Wahid, 1991). Dikatakan paling mendasar karena nilai-nilai pancasila perlu untuk dilaksanakan bahkan dalam tataran kehidupan dalam keluarga. karena lingkungan keluarga merupakan lingkungan yang paling mempengaruhi perkembangan kehidupan seseorang.

Perkembangan masyarakat Indonesia saat ini khusunya diera globalisasi baik globalisasi dalam bidang industri maupuan globalisasi ideologi secara universal, mengharuskan masyarakat Indonesia untuk tetap menghayati dan melestarikan nilainilai Pancasila dalam berbagai aspek kehidupan, supaya nilai-nilai Pancasila ini tetap terjaga kemurniannya sebagai pedoman hidup bangsa Indonesia. Dalam pembukaan UUD, menyatakan mengenai Pancasila sebagai dasar Negara. bahkan Pancasila memiliki peran sebagai sumber dari segala sumber hukum di Indonesia.

Tujuan penelitian ini yaitu untuk mengetahui pentingnya penerapan pancasila dalam kegiatan berorganisasi di Indonesia, khsusnya dalam organisasi yang bergerak 
dalam kegiatan keagamaan. Supaya dapat terlihat pentingnya eksistensi pancasila untuk persatuan bangsa Indonesia.

\section{Metode Penelitian}

Dalam penelitian ini, penulis menggunakan jenis penelitian Empiris, penelitian empiris merupakan penelitian yang dilakukan dengan cara menganalisa gejala sosial yang ada secara empirik dari data primer. Namun disisi lain, penelitian juga didukung dengan data sekunder dalam hal ini bahan pustaka. Khususnya perundangan dan bahan hukum berupa library based, focusing on reading analiysis of the primary and secondary materials (Soerjono Soekanto dan Sri Mamudji, 2006).

Dengan demikian penulis menggunakan metode kualitatif, metode kualitatif pendekatan yang digunakan yaitu induktif, dengan cara mengumpulkan, menganalisa, dan mengabstraksikan yang kemudian memunculkan teori-teori sebagai suatu penemuan penelitian kualitatif (Lexy. J.Moeloeng, 2009). Teknik pengumpulan data yang dilakukan oleh penulis yaitu; (1) Wawancara; dilakukan oleh peneliti terhadap para mahasiswa universitas duta bangsa yang tergabung dalam organisasi kemahasiswaan FOKAM (2) Observasi Langsung; Peneliti melakukan pengamatan dan meneliti langsung ke tempat yang menjadi objek penelitian, yaitu wawancara langsung pada anggota dan ketua Fokam. (3) Studi Pustaka (library research); Peneliti menggunakan sumber data dari berbagai peraturan khususnya UUD 1945, buku-buku yang berkaitan dengan identitas nasional, artikel, surat kabar, bulletin, jurnal, dan lain sebagainya.

\section{Hasil dan Pembahasan}

\section{Pancasila Sebagai Ideologi Terbuka di Indonesia.}

Pada dasarnya, pengertian ideologi berasal dari kata Idea yang memiliki arti gagasan, konsep, serta cita-cita yang hendak dicapai. Sedangkan logi berasal dari kata logos yang berarti ilmu. Dengan demikian, pengetian dari Ideologi yaitu ideide atau gagasan atau ilmu, yang membahas mengenai cita-cita yang hendak dicapai. Sedangkan Kaelan mendefinisikan ideologi sebagai ide-ide ataupun ajaran tentang pengertian dasar (Kaelan, 2013). Sedangkan menurut kamus besar bahasa Indonesia, ideologi di artikan sebagai suatu kumpulan konsep yang memiliki sistem, yang dijadikan sebagai dasar dalam berpendapat untuk memberikan arah dan tujuan melangsungkan hidup.

Bahkan ideologi diartikan sebagai suatu paham maupun teori juga tujuan yang berkaitan dengan politik (Indonesia, 2008) Sehingga di Indonesia, Pancasila juga memiliki peranan dalam kegiatan politik. Politik yang diartikan sebagai cara untuk pencapaian tujuan, maka segala yang menjadi cita-cita bangsa Indonesia, untuk pencapaiannya memerlukan Pancasila sebagai landasannya. Disisilain, karena merupakan bentuk dari ide atau gagasan yang dicita-citakan, maka Pancasila sebagai ideologi pancasila memiliki peranan yang sangat penting pula dalam upaya memelihara integrasi nasional(Ubaidillah, Suyitno, \& Juwana, 2012) Bukan tanpa alasan bahwa pancasila penting sebagai upaya memelihara integrasi nasional, hal 
ini dikarenakan begitu kompleks nya masyarakat Indonesia pada aspek budaya, agama, maupun suku, maka pancasila sangatlah penting untuk tetap di lestarikan nilai-nilainya sebagai suatu dasar ideologi nasional yang mempersatukan bangsa.

Di Indonesia yang menganut sistem Demokrasi berdasarkan Pancasila ini pun menunjukkan bahwa pancasila merupakan suatu ideologi yang juga masuk dalam ranah politik negara. Selain itu juga menunjukkan keterbukaan pancasila sebagai suatu ideologi, karena adanya pemikiran demokrasi, meskipun sebenarnya demokrasi yang dianut nilai-nilainya telah ada dalam kehidupan bangsa Indonesia.

Pancasila sendiri di Indonesia memiliki kedudukan sebagai dasar Ideologi yang memiliki sifat terbuka. Sedangkan ciri dari ideologi terbuka misalnya nilainilai didalamnya, termasuk cita-cita yang menjadi tujuan utamanya tidak dipaksakan dari luar, namun ada dalam diri bangsa Indonesia. Sehingga apabila digali di kehidupan masyarakat Indonesia, maka akan ditemukan pula nilai-nilai tersebut, untuk mencapai tujuan nasional bangsa. Penjabaran mengenai ideologi yang bersifat terbuka dapat dilaksanakan dengan interpretasi yang lebih kritis dan dengan rasional (Soeryanto, 1991). Bahwa pada penerapannya khususnya di Indonesia, Pancasila dapat mengikuti perkembangan/ kebutuhan masyarakat Indonesia. Perkembangan masyarakat saat ini misalnya kebutuhan untuk dapat mengembangkan diri melalui kegiatan berorganisasi, sudah sewajarnya memerlukan jaminan kepastian atau perlindungan dari negara.

Pancasila sebagai Ideologi terbuka memiliki ciri bahwa ideologi tersebut dapat berinteraksi terhadap perkembangan zaman, maupun dinamika internal masyarakat. Dapat ditemukan bahwa sumber dari ideologi terbuka tersebut terdapat dalam penjelasan umum UUD 1945. Wujud implementasi ideologi pancasila sebagai ideologi yang mampu mengikuti perkembangan zaman yaitu tetap eksisnya pancasila dalam era Industri 4.0 yang saat ini sedang berlangsung. Perkembangan teknologi informasi yang sangat pesat memungkinkan banyaknya ideologi yang masuk ke Indonesia melalui sistem informasi. Khususnya melalui internet yang saat ini banyak sekali digunakan oleh masyarakat Indonesia. Namun ditengah banyaknya ideologi yang masuk ke Indonesia melalui sistem informasi, Pancasila tetap tidak mengalami perubahan.

\section{Ideologi Pancasila dalam Pelaksanaan Kehidupan Beragama}

Pada dasarnya Pancasila dibentuk bukan untuk kelompok khusus atau kelompok tertentu di Indonesia, melainkan untuk seluruh warga negara indonesia. Tanpa memandang suku, ras dan agama pada masyarakatnya. Para pendiri bangsa pada awal kemerdekaan berhasil keluar dari adanya rutinitas pada pandangan hidup bangsanya melalui penalaran dan pemikiran (Hariyono, Hoang, \& Jo, 2014) Pada perkembangan perpolitikan di Indonesia saat ini, pelaksanaan pancasila diharapkan tidak dicampakkan oleh para elit negara. Karena pancasila sebagai dasar ideologi perlu untuk di laksanakan pada aspek kehidupan masyarakat baik dalam kehidupan politik maupun organisasi (dalam hal ini khususnya kehidupan beragama). 
Sehingga tindakan pencampakan pancasila bisa mengakibatkan adanya kelumpuhan dalam tubuh bangsa Indonesia.

Peranan Pancasila sebagai Grundnorm/staatsfundamentalnorm, menunnjukkan bahwa pancasila merupakan kaidah fundamental negara Indonesia pada tataran Normtif. Kemudian norma dasar atau fundamental tersebut dijabarkan dalam UUD 1945 yang diharapkan dapat menjadi tempat berpijak untuk menata kehidupan berbangsa dan bernegara. Sehingga tujuan nasional bangsa Indonesia dalam pembukaan UUD 1945 berupa;

a. Memberikan perlindungan bagi seluruh bangsa Indonesia dan segenap tumpah darah Indonesia.

b. Meningkatkan kesejahteraan umum

c. Meningkatkan program mencerdaskan kehidupan bangsa

d. Turut serta dalam ketertiban dunia dengan berdasarkan kemerdekaan dan perdamaian abadi serta keadilan sosial.

Membahas mengenai Pancasila dalam berorganisasi, Marwan Adam juga pernah membahas mengenai munculnya gerakan Negara Islam Indonesia (NII) yang pada perjalanannya memiliki ideologi bersebrangan dengan ideologi Pancasila, Bahwa bukan pada agama yang menjadi permasalahan dalam kehidupan negara, namun lebih kepada pelaksanaan pengambilan ideologi pada agama yang nilainya bertentangan dengan ideologi pancasila.

Pancasila sebagai ideologi terbuka mampu untuk mengikuti perkembangan masyarakat, dapat menjadi hukum yang progresif, ini dapat dilihat dengan adanya partai politik bahkan organisasi masyarakat (ormas) yang belandaskan hukum agama yang saat ini ada di Indonesia. Namun pancasila tetap tidak berubah. Karena disisi lain pancasila bisa berperan sebagai filter masuknya nilai-nilai dari ideologi lain. Sehingga walaupun muncul parpol maupun ormas yang berlandaskan agama, ormas dan parpol tersebut masih dapat hidup di Indonesia sepanjang ideologi dasar yang digunakan tidak bertentangan dengan nilai-nilai pancasila. hal tersebut juga nampak pada saat ini yang terjadi di Indonesia pada era pemerintahan pak Jokowi, adanya klasifikasi ormas yang ada di Indonesia. Bisa dikatakan bahwa klasifikasi ormas ini memiliki tujuan supaya ormas-ormas yang ada di Indonesia tetap pada nilai-nilai dasar, bahwa mereka ada di dalam NKRI yang berlandaskan Pancasila, sehingga jangan sampai nilai-nilai pancasila ini hilang karena adanya ormas-ormas yang memiliki peran sebagai embrio perpecahan dalam tubuh NKRI. Klasifikasi ormas tersebut dapat menjadi alat untuk menyisir ormas mana yang ternyata didalamnya memiliki odeologi yang bertentangan dengan Pancasila.

Dalam kehidupan beragama di Indonesia, Indonesia telah menjamin mengenai kebebasan beragama dan menjalankan kepercayaannya tersebut didalam konstitusi. Namun perlu diingat pula bahwa dalam masyarakat Indonesia juga memiliki prinsip "dimana bumi di pijak disitu langit dijunjung". Dengan melihat kedua hal tersebut, maka ini berarti dalam kehidupan beragama kita juga wajib untuk menghormati negara, sedangkan negara menghormati kebebasan kehidupan 
beragama yang dituangkan dalam pancasila, UUD, maupun kebijakan lain dibawahnya.

\section{Urgensi Pelaksanaan Pancasila Sebagai Dasar Ideologi dalam Lingkungan Organisasi Keagamaan.}

Tidak dapat di pungkiri, bahwa masyarakat Indonesia merupakan masyarakat yang religi, yang sangat menjunjung nilai-nilai keagamaan yang dianutnya. Maka ketika terdapat suatu wadah berbentuk suatu organisasi, maka organisasi yang merupakan salah satu lingkup yang membawa perubahan dalam diri manusia, khusunya para nggotanya, juga berlaku pada lingkungan organisasi keagamaan. Ideologi agama yang merupakan ideologi yang bersumber dari luar Indonesia, tentulah ada beberapa hal yang berbeda dengan adat budaya Indonesia. Organisasi keagamaan merupakan forum yang digunakan oleh masyarkat untuk berkumpul dan mengembangkan nilai-nilai keagamaannya. Sebagai suatu organisasi yang hidup dalam negara kesatuan republik Indonesia, maka sudah seharausnya pelaksanaan-pelaksanaan program dalam organisasi (apapun itu) tidak boleh bertentangan dengan nilai, norma atau kaidah yang telah ada dalam masyarakat Indonesia, dalam hal ini tidak boleh bertentangan dengan nilai-nilai Pancasila yang merupakan dasar ideologi bangsa dan sumber dari segala sumber hukum di Indonesia.

Paparan radikalisme dalam suatu organisasi dengan berkedok organisasi keagamaan sangatlah mudah untuk dimanfaatkan. Seperti yang pernah di ungkapkan oleh ali imron (terpidana kasus terorisme), bahwa mereka hanya membutuhkan waktu 2 jam saja untuk dapat merekrut seseorang dan mau menjadi calon 'pengantin' dalam bom bunuh diri. Bahkan untuk mengembangkan jaringannya, mereka sangat aktif berggerak melalui media internet. Perkembangan teknologi informasi saat ini yang sangat pesat, semakin mendesak bagi pemerintah untuk menfilter berbagai informasi yang masuk dalam lingkungan negara Indonesia. Hal ini dikarenakan banyaknya pengguna teknologi informasi di Indonesia yang ternyata telah terpapar ideologi radikal yang masuk melalui internet. Misalnya saja terdapat video pada youtube yang mengunggah tentang ideologi radikal bahkan sejak masih taman kanak-kanak. Hal ini sangat memperihatinkan, karena lingkungan agama yang seharusnya memberikan pengayoman bagi seluruh umat manusia, disalah gunakan dengan adanya tafsiran yang bertentangan dengan nilai-nilai pancasila.

Hal inilah yang menjadi tantangan bagi pemerintah, untuk mensinkronkan faham agama dengan faham nasionalitas bangsa Indonesia. Supaya terjadi sinergi yang baik antara agama dan negara. Sehingga masyarakat yang berada di bawahnyapun menjadi semakin kondusif terhadap adanya perubahan dan perbedaan dalam lingkungannya. Pemerintah memerlukan adanya instrumen-instrumen tambahan (bisa berupa kebijakan baru maupun pembentukan lembaga baru) sebagai tangan pemerintah untuk tetap menjaga ideologi bangsa Indonesia tetap pada 
Pancasila. Bahwa ada yang mengatakan mengenai radikalisme saat ini hanyalah merupakan suatu proyek. Namun, apapun itu , selain radikalisme, paham apapun, sebenarnya pemerintah memiliki kewenangan untuk tetap menjaga ideologi Pancasila, dengan cara apapun pemerintah wajib untuk mengupayakannya.

\section{Ideologi Pancasila dalam Pelaksanaan Kehidupan Berorganisasi di Forum Komunikasi Antar Mahasiswa Muslim Universitas Duta Bangsa Surakarta.}

Dalam upaya peningkatan persatuan Indonesia, perlu adanya pengejawantahan nilai-nilai Pancasila dalam berbagai aspek kehidupan masyarakat Indonesia. Terlebih saat ini dengan era yang makin globalnya ilmu pengetahuan maupun ideologi. Ada beberapa ideologi dari luar yang kini telah masuk di Indonesia, diantaranya ideologi liberal yang mulai memasuki pasar ekonomi Indonesia. Selain itu, yang saat ini tidak pernah basi untuk dibahas di Indonesia yaitu mengenai agama. 6 Agama yang disahkan oleh pemerintah saat ini merupakan agama-agama yang asalnya bukan dari Indonesia.

Dengan asal yang bukan dari Indonesia, tentulah memiliki perbedaaan terhadap nilai-nilai Pancasila yang merupakan ideologi yang bersumber dari karakter, nilai-nilai budaya bangsa Indonesia sendiri. Adanya perbedaan pandangan inilah yang perlu disikapi dengan kebijaksanaan oleh seluruh warga negara Indonesia yang beragama. Bahwa, pelaksanaan nilai-nilai agama tidak boleh bertentangan dengan nilai-nilai Pancasila, dan pelaksanaan nilai pancasila tidak bertentangan dengan nilai agama, karena nilai-nilai pancasila masih bersifat universal, selain itu juga karena ini sebagai penghargaan negara terhadap warga negara dalam kehidupan beragamanya.

Dalam kehidupan berorganisasi di forum komunikasi antar mahasiswa muslim di universitas duta bangsa surakarta, meskipun merupakan suatu wadah keagamaan, tidak secara serta merta menjadikan forum tersebut sebagai forum yang melupakan ideologi pancasila. beberapa kegiatan yang berkaitan dengan keagamaan, misalnya kajian Alquran, tidak menggunakan nara sumber yang dipandang oleh masyarakat sebagai pengikut aliran radikalisme. Hal ini bertujuan supaya organisasi Fokam tetap pada tujuan awalnya yaitu meningkatkan ikatan mahasiswa muslim universitas duta bangsa, meningkatkan keimanan dan ketaqwaan, dan bermanfaat bagi masyarakat (tanpa memandang agama) berdasarkan toleransi keberagaman.

Terkadang organisasi Fokam juga melakukan kegiatan sosial yang bersifat umum, Misalnya kegiatan rutin berupa donor darah dan bakti sosial di lingkungan kampus. Bakti sosial yang dilakukan tidak hanya diberikan kepada kelompok tertentu yang beragama sama, namun bakti sosial ditujukan kepada masyarakat pada umumnya. Beberapa kegiatan keagamaan pun, misalnya adanya kajian keagamaan rutin, dilakukan intern tanpa ada maupun tanpa mengganggu penganut agama lain yang ada di lingkungan kampus. 
Widi Nugrahaningsih dan Margaretha Evi Yuliana

\section{Kesimpulan}

Eksistensi Dan Penerapan Pancasila Sebagai Dasar Ideologi Di Organisasi Fokam (Forum Komunikasi Antar Mahasiswa Muslim) Universitas Duta Bangsa Surakarta, menunjukkan bahwa Pancasila masih sangat dibutuhkan dalam kehidupan sehari-hari. Khususnya dalam kehidupan berorganisasi. Dalam berorganisasi, Fokam di Universitas Duta Bangsa tetap menempatkan Pancasila sebagai dasar ideologi. Ini ditunjukkan dengan adanya berbagai kegiatan kemahasiswaan baik kegiatan yang berkaitan dengan keagamaan maupun kegiatan sosial. Dalam kegiatan keagamaan, di organisasi Fokam tidak ditemukan ajaran yang menjurus kepada tindakan-tindakan yang saat ini sering dikatakan oleh masyarakat sebagai tindakan radikal. Selain itu, dalam kegiatan sosial, tetap dilakukan dengan tidak memandang apakah sasaran kegiatan sosial dari kalangan muslim atau tidak. 


\section{BIBLIOGRAFI}

Agus, A. A. (2016). Relevansi Pancasila Sebagai Ideologi Terbuka di Era Reformasi. Jurnal Office, 2(2), 229-238.

Asmaroini, A. P. (2017). Menjaga Eksistensi Pancasila Dan Penerapanya Bagi Masyarakat di Era Globalisasi. JPK: Jurnal Pancasila Dan Kewarganegaraan, 1(2), 50-64.

Hariyono, J., Hoang, V.-D., \& Jo, K.-H. (2014). Moving object localization using optical flow for pedestrian detection from a moving vehicle. The Scientific World Journal, 2014.

Indonesia, K. B. B. (2008). Jakarta: Pt. Gramedia Pustaka Utama.

Kaelan, M. S. (2013). Negara Kebangsaan Pancasila. Paradigma, Yogyakarta.

Lexy. J.Moeloeng. (2009). Metodologi Penelitian Kualitatif. Bandung: Remaja Rosdakarya.

Setiono. (2005). Pedoman terhadap metodologi penelitian hokum. Surakarta.

Soerjono Soekanto dan Sri Mamudji. (2006). Penelitian Hukum Normatif Tinjauan Singkat. Jakarta: Rajawali Pers.

Soeryanto, P. (1991). Pancasila sebagai Ideologi Ditinjau dari Segi Pandangan Hidup Bersama. BP-7 Pusat, Jakarta.

Sutopo, H. (1992). Metode Penelitian Hukum. Jakarta: PT.Gramedia Pustaka Utama.

Ubaidillah, U., Suyitno, S., \& Juwana, W. E. (2012). Pengembangan Piranti Hibrid Termoelektrik-Sel Surya Sebagai Pembangkit Listrik Rumah Tangga. Jurnal Litbang Provinsi Jawa Tengah, 10(2), 194-211.

Wahid, A. (1991). Pancasila sebagai Ideologi Kaitannya dengan kehidupan Beragama dan Berkepercayaan terhadap Tuhan Yang Maha Esa. Dalam Oetojo Oesman Dan Alfian (Peny.), Pancasila Sebagai Ideologi, Jakarta: BP7 Pusat. 